\title{
Impaired Glucose Homeostasis in Insulin-like Growth Factor Binding Protein-1 Transgenic Mice
}

\author{
Kadaba Rajkumar, Michal Krsek, S. Thameem Dheen, and Liam J. Murphy \\ Department of Internal Medicine and Department of Physiology, University of Manitoba, Winnipeg R3E 0W3 Canada
}

\begin{abstract}
Transgenic mice that overexpressed IGFBP-1 are hyperinsulinemic in the first week of life and gradually develop fasting hyperglycemia. In adult transgenic mice, the hypoglycemic response to IGF-I but not insulin or des (1-3) IGF-I was attenuated $(P<0.05)$ compared with wild-type mice. Furthermore, in isolated adipocytes from transgenic mice, the stimulatory effect of IGF-I but not insulin on 2-deoxy$\left[{ }^{3} \mathrm{H}\right]$-glucose uptake was reduced $(P<0.02)$. In contrast, in isolated soleus muscle, the effects of both IGF-I and insulin on 2-deoxy- ${ }^{3} \mathrm{H}$-glucose uptake and on $\left[{ }^{3} \mathrm{H}\right]$-glucose incorporation into glycogen were significantly reduced compared to wild-type mice. The decline in specific activity of the 2-deoxy- ${ }^{3} \mathrm{H}$-glucose, a measure of glucose appearance in the circulation, was more marked in transgenic animals $(P<0.05)$. In addition, tissue uptake of glucose was significantly higher in diaphragm, heart, intestine, liver, soleus muscle, and adipose tissue from fasting transgenic mice. Plasma concentrations of alanine, lysine, and methionine were also elevated in transgenic mice. These data suggest that overexpression of IGFBP-1 attenuates the hypoglycemic effect of endogenous IGF-I, which is initially compensated for by enhanced pancreatic insulin production. However, in adult mice pancreatic insulin content is reduced, insulin resistance is demonstrable in skeletal muscle and fasting hyperglycemia develops. (J. Clin. Invest. 1996. 98: 1818-1825.) Key words: diabetes • IGF-I • insulin • 2-deoxyglucose uptake $\bullet$ pancreatic islets
\end{abstract}

\section{Introduction}

The insulin-like growth factor binding proteins (IGFBPs) ${ }^{1}$ are present in the serum, other biological fluids and tissue extracts. These proteins bind the insulin like growth factors (IGF-I and IGF-II) with affinities comparable to the type I IGF receptor

Address correspondence to Liam J. Murphy M.B., Ph.D., Departments of Internal Medicine and Physiology, University of Manitoba, Winnipeg R3E OW3, CANADA. Phone: 204-789-3779; FAX: 204774-7751.

Received for publication 4 April 1996 and accepted in revised form 5 August 1996.

1. Abbreviations used in this paper: IGFBP-1, insulin-like growth factor binding-1; IGF-1, insulin-like growth factor-1.

J. Clin. Invest.

(c) The American Society for Clinical Investigation, Inc. 0021-9738/96/10/1818/08 \$2.00

Volume 98, Number 8, October 1996, 1818-1825
(1). Although the IGFs are only 5-10\% as potent as insulin in terms of stimulating glucose transport in vitro and inducing hypoglycemia in vivo $(2,3)$, they are present in the circulation in concentrations approaching 100 times that of insulin; 100 $800 \mathrm{ng} / \mathrm{ml}$ versus $1-4 \mathrm{ng} / \mathrm{ml}$. Thus, in addition to the other potential functions that have been proposed for the IGFBPs, one important function is to limit the hypoglycemic effects of the circulating IGF-I and IGF-II (4). However, a small proportion of the immunoreactive IGF-I present in the circulation, probably considerably less than $1 \%$ of the total, is not bound to binding proteins and may be important in glucose homeostasis.

Six members of the IGFBP gene family have now been identified. Although they share approximately 50\% homology, they are derived from separate genes and show different regulation and tissue-specific expression (1). Of the IGFBPs which have been shown to be present in the circulation, IGFBP-1, the first of these binding proteins to be isolated may be the most important in regulating the insulin-like activity of the IGFs $(5,6)$. Although IGFBP-3 is responsible for the majority of the IGF binding capacity in the serum virtually all the IGFBP-3 present in the circulation is saturated with IGF-I or IGF-II (7). Furthermore, IGF-I or II bound to IGFBP-3 tends to turn over less rapidly than free IGF or IGF bound to the other IGFBPs present in the circulation $(4,8)$. Although IGFBP-I is present in much lower concentrations than IGFBP-3, and has a lower affinity for IGFs than IGFBP-3, the levels of IGFBP-1 in the circulation fluctuate quite widely in response to the nutritional state (1). Unlike IGFBP-3, IGFBP-1 is largely unsaturated (5). IGFBP-1 is present at low concentrations in the circulation and the levels are inversely regulated by insulin $(5,9,10)$. The serum IGFBP-1 concentration demonstrates a circadian rhythm which mimics the diurnal variations in insulin resistance (11).

We have previously reported that transgenic mice that overexpress rat IGFBP-1 in a variety of tissues demonstrate fasting hyperglycemia and glucose intolerance (12). Here we have extended those studies and examined the hypoglycemic effects of IGF-I and des (1-3) IGF-I, a naturally occurring variant with markedly reduced affinity for IGFBPs, in IGFBP-1 transgenic mice.

\section{Methods}

Animal studies. The generation and characterization of the transgenic mice have been described in detail elsewhere (12). The transgene consisted of an $\sim 5$-kb rat genomic fragment containing the entire coding region of the IGFBP-1 gene inserted downstream of the mouse phosphoglycerate kinase promoter. Homozygous transgenic mice of the 277A strain were used for all studies. Wild-type, nontransgenic mice of the same genetic background were derived from the F1 cross of the founders with a CD-1 mouse were bred in a similar fashion to the transgenic mice. All studies were performed on overnight fasted male mice which were between 55-60 d of age unless otherwise stated. Animal experimentation was performed in accordance 
with protocols approved by the Animal Care Committee of the Faculty of Medicine, University of Manitoba.

Hypoglycemic effects of IGF-I and des (1-3) IGF-I. Fasting male mice, $\sim 60 \mathrm{~d}$ of age, were anesthestized with Avertin and bled via the retroorbital sinus. Varying amounts of human recombinant IGF-I or des (1-3) IGF-I, both generously provided by Genentech Inc. (San Francisco, CA), were diluted in saline and were administered subcutaneously in a total volume of $100 \mu \mathrm{l}$. Blood $(40 \mu \mathrm{l})$ was collected at the indicated time points via the retroorbital sinus using heparinized micropipettes. Glucose was measured in whole blood using a glucose analyzer (YSI 2300; Yellow Springs, OH).

Measurement of insulin and amino acids. The insulin concentration in fasting plasma samples and pancreatic extracts was measured by radioimmunoassay using an assay kit from Pharmacia Canada Inc., (Baie D'Urfe, Quebec). For the glucose challenge blood was collected from 60-d-old fasting mice at time 0 and 5 min after an injection of $1 \mathrm{~g} / \mathrm{kg}$ body wt i.v. For the glucagon challenge, $100 \mu \mathrm{g} / \mathrm{kg}$ body wt i.v. was injected and blood was collected 4 min later for determination of the plasma insulin concentration. Pancreatic insulin was extracted as previously described (13). Plasma amino acids were measured by cation-exchange chromatography using an automated amino acid analyzer.

Adipocyte isolation and incubation. Male mice, $\sim 60-90 \mathrm{~d}$ old were killed by cervical dislocation. The epididymal fat pads were excised and minced in petri dishes containing Eagle's minimal essential medium (MEM; GIBCO BRL; Burlington, Ontario). Adipocytes pooled from three to five mice were used in each experiment. The adipocytes were isolated by shaking minced tissue at $37^{\circ} \mathrm{C}$ for $1 \mathrm{~h}$ in MEM containing $25 \mathrm{mM}$ Hepes, $0.5 \mathrm{mg} / \mathrm{ml}$ collagenase type II (Sigma Chemical Co.; St. Louis, MO), and $4 \%$ of bovine serum albumin. After isolation, the cells were washed once in MEM and three times in glucosefree uptake buffer $\left(120 \mathrm{mM}, \mathrm{NaCl}, 1.2 \mathrm{mM}, \mathrm{MgSO}_{4} .7 \mathrm{H}_{2} \mathrm{O}, 2.0 \mathrm{mM}\right.$ $\mathrm{CaCl}_{2}, 2.5 \mathrm{mM} \mathrm{KCl}, 1.0 \mathrm{mM} \mathrm{NaH} \mathrm{PO}_{4}, 20 \mathrm{mM}$ Hepes, $1 \mathrm{mM}$ sodium pyruvate, and $1 \%$ bovine serum albumin, $\mathrm{pH} 7.4$ ). Adipocytes were then resuspended in $600 \mu \mathrm{l}$ of glucose free uptake buffer with or without hormones and incubated in a shaking water bath at $37^{\circ} \mathrm{C}$ for $1 \mathrm{~h}$ in sealed tubes gased with a mixture of $95 \% \mathrm{O}_{2}$ and $5 \% \mathrm{CO}_{2}$. At the end of this period 2-deoxy- $\left[{ }^{3} \mathrm{H}\right]$-glucose (Dupont, Canada Inc.; Mississauga, Ontario) at a final concentration $0.1 \mathrm{mM}$ and specific activity of $1.6 \mu \mathrm{Ci} / \mathrm{ml}$ was added. Uptake was terminated after $3 \mathrm{~min}$ by centrifugation through the silicon oil. Cell pellets were dissolved in $800 \mu \mathrm{l}$ of scintillant (Universol; Fisher Scientific; Winnipeg, Manitoba) and counted in a beta counter.

Soleus muscle isolation and incubation. Male mice $\sim 60 \mathrm{~d}$ old were anesthetized by an i.p. injection of Avertin after an overnight fast. The soleus muscles were removed and tied to stainless steel clips. All incubations were carried out at $37^{\circ} \mathrm{C}$ under an atmosphere of $95 \% \mathrm{O}_{2}$, $5 \% \mathrm{CO}_{2}$ in $1 \mathrm{ml}$ of Krebs-Henseleit bicarbonate buffer $(\mathrm{NaCl} 119.4$ $\mathrm{mM}, \mathrm{KCl} 4.74 \mathrm{mM}, \mathrm{KH}_{2} \mathrm{PO} 41.20 \mathrm{mM}, \mathrm{MgSO}_{4} .7 \mathrm{H}_{2} \mathrm{O} 1.20 \mathrm{mM}, \mathrm{NaHCO}_{3}$ $25 \mathrm{mM}, \mathrm{CaCl}_{2} 2.52 \mathrm{mM}$, bovine serum albumin RIA grade $1 \%, \mathrm{Na}$ pyruvate $2 \mathrm{mM}$ ). After a preincubation period of $15 \mathrm{~min}$ intended to remove endogenous insulin, muscles were incubated for $60 \mathrm{~min}$ in the presence or absence of hormones at the indicated concentrations. At the end of this period 2-deoxy- $\left[{ }^{3} \mathrm{H}\right]$-glucose at a final concentration 1 $\mathrm{mmol} /$ liter and specific activity of $1.2 \mu \mathrm{Ci} / \mathrm{ml}$ was added and incubation continued for additional $15 \mathrm{~min}$. Uptake was terminated by washing in ice-cold saline for $30 \mathrm{~min}$. Muscles were then dissolved in $300 \mu \mathrm{l}$ of $1 \mathrm{~N} \mathrm{NaOH}$. After neutralization with equimolar $\mathrm{HCl}, 5-\mu \mathrm{l}$ aliquots were taken for protein determination using the Bio-Rad protein assay method (Bio-Rad Laboratories Ltd., Mississauga, Ontario) Radioactivity was determined in $100-\mu l$ aliquots using a beta scintillation counter

Glycogen synthesis was assessed under basal conditions and in response to various concentrations of insulin, IGF-I and des (1-3) IGF-I by measuring $5-\left[{ }^{3} \mathrm{H}\right]$-glucose incorporation into glycogen over a 60 min period. Soleus muscle was incubated as described above except that the buffer contained $1 \mu \mathrm{Ci}$ 5-[ $\left[{ }^{3} \mathrm{H}\right]$-glucose (Dupont, Canada Inc.) and $5 \mathrm{mM}$ glucose. At the completion of the incubation the muscle was washed extensively with ice-cold saline and hydrolyzed in $0.5 \mathrm{ml}$ of $1 \mathrm{~N} \mathrm{NaOH}$ at $70^{\circ} \mathrm{C}$. An aliquot was retained for protein determination and the radiolabeled glycogen was precipitated from the hydrolysate in the presence of carrier glycogen by addition of ethanol to a final concentration of $66 \%$ and incubation at $-20^{\circ} \mathrm{C}$. The precipitate was washed extensively with $66 \%$ ethanol and dissolved in water before determination of radioactivity. Glycogen synthesis was expressed in terms of nanomoles of glucose incorporated per milligram of muscle protein.

2-deoxy-[ $\left[{ }^{3} \mathrm{H}\right]$-glucose uptake and clearance studies. Fasted male mice $\sim 60 \mathrm{~d}$ old were anesthetized by an intraperitoneal injection of Avertin. 2-deoxy- $\left[{ }^{3} \mathrm{H}\right]$-glucose was administered as a bolus via the tail vein and blood was immediately sampled $(\sim 0.5 \mathrm{~min}$ after injection) via the retroorbital sinus to determine the specific activity of the labeled glucose pool. For determination of specific activity, 2-deoxy-glucose was considered to be equivalent to glucose and specific activity was expressed as cpm/ nmol of glucose. 2-deoxy-[ $\left.{ }^{3} \mathrm{H}\right]$-glucose was administered at a dose of $500 \mu \mathrm{Ci} / \mathrm{kg}$ body wt to wild type mice. In pilot studies it was determined that the amount of 2-deoxy- $\left[{ }^{3} \mathrm{H}\right]$-glucose to achieve the same specific activity had to be increased by $25 \%$ because of the hyperglycemia in transgenic mice. For glucose clearance studies, blood was sampled at $0.5,5,10,20$, and $40 \mathrm{~min}$ after injection. The mice were then exsanguinated and various tissues harvested for determination of 2-deoxy- $\left[{ }^{3} \mathrm{H}\right]$-glucose. Tissue was solubilized using Solvable (Dupont, Canada Inc.) at a concentration of $100 \mathrm{mg} / \mathrm{ml}$ and $\mathrm{H}_{2} \mathrm{O}_{2}, 100 \mu \mathrm{l} / \mathrm{ml}$ was added. An aliquot was taken for determination of 2-deoxy- $\left[{ }^{3} \mathrm{H}\right]$-glucose 6-phosphate. The tissue glucose utilization index (GUI) was used to correct for the different amounts of 2-deoxy- $\left[{ }^{3} \mathrm{H}\right]$-glucose administered and the difference in the rate of change of the specific activity of the glucose pool (14). The GUI was derived from the formula:

$$
\text { GUI }=\frac{\left[2 \text {-deoxy- }\left[{ }^{3} \mathrm{H}\right] \text {-glucose 6-phosephate }\right]_{t}}{\int_{0}^{t} S A \cdot d t}
$$

where 2-deoxy- $\left[{ }^{3} \mathrm{H}\right]$-glucose 6-phosphate concentration is expressed as cpm per $100 \mathrm{mg}$ of tissue, $t=40 \mathrm{~min}$ and SA is the specific activity of the glucose pool expressed as cpm of 2-deoxy- $\left[{ }^{3} \mathrm{H}\right]$-glucose per nmol of glucose. Thus tissue 2-deoxy- $\left[{ }^{3} \mathrm{H}\right]$-glucose uptake derived from these data reflects net glucose uptake over the 40-min period.

Statistical analysis. All data have been presented as the mean \pm SEM. Significant differences between transgenic and wild-type mice were determined for various parameters using either Student's $t$-test or an analysis of variance followed by Dunnett's $t$-test where multiple comparisons with one treatment group were required.

\section{Results}

The fasting blood glucose levels in transgenic and wild-type mice at various ages are shown in Fig. 1. Newborn and 1-wk-old mice were food-deprived for only 4 and $12 \mathrm{~h}$, respectively, since they could not survive a prolonged fast. Older mice were fasted for $18 \mathrm{~h}$. Fasting blood glucose levels were similar in the two groups of younger mice (Fig. 1). However, fasting hyperglycemia was seen in 2-wk-old transgenic mice and the difference in fasting blood glucose levels in transgenic and wild-type mice became more apparent after weaning. In contrast, plasma insulin levels were markedly elevated in early life in transgenic compared to wild-type mice (Fig. 1). Although fasting hyperinsulinemia persisted in adult transgenic mice, the difference in insulin concentrations between transgenic and wild-type mice was less marked. There was a steady decline in the insulin to glucose ratio in both transgenic and wild type mice. However, the decline in this ratio was more marked in transgenic mice; from 17.4 on day 1 to $4.62 \mathrm{pmol} / \mathrm{mmol}$ on day 60 in transgenic 

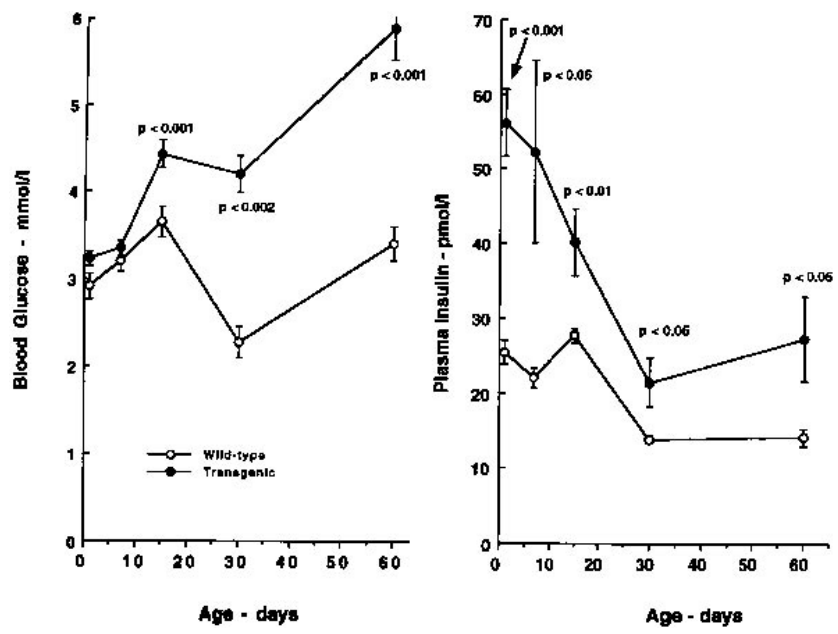

Figure 1. Age-related changes in the fasting blood glucose and plasma insulin concentrations in transgenic and wild-type mice. Mice were fasted for 4 or $12 \mathrm{~h}$ for day 1 and 7 , respectively. All other mice were fasted for $18 \mathrm{~h}$. The number of animals per group ranged from 9-19. The significant differences between transgenic and wild-type mice at various ages are indicated.

mice versus 8.72 to $4.13 \mathrm{pmol} / \mathrm{mol}$ in wild-type mice. Pancreatic insulin content was significantly elevated in the early neonatal period in transgenic mice compared to wild type mice (Table I). In both groups, there was an age-related decline but this was more marked in transgenic mice. As a consequence,
Table I. Age Related Changes in Pancreatic Insulin Content

\begin{tabular}{lccc}
\hline Age & Wild-type mice & Transgenic mice & \\
\hline Day 1 & $49.0 \pm 2.6$ & $60.5 \pm 2.5$ & $P<0.007$ \\
Day 7 & $65.2 \pm 2.3$ & $90.9 \pm 8.6$ & $P<0.014$ \\
Day 14 & $55.6 \pm 1.6$ & $75.9 \pm 3.2$ & $P<0.001$ \\
Day 30 & $25.0 \pm 0.8$ & $23.7 \pm 0.8$ & NS \\
Day 60 & $28.6 \pm 0.8$ & $22.5 \pm 1.3$ & $P<0.003$
\end{tabular}

Data represent the mean \pm SEM for $6-10$ mice per group and is expressed as ng/mg tissue.

adult transgenic mice had significantly lower pancreatic insulin concentrations than wild-type mice. However, despite this reduction in pancreatic insulin content, fasting transgenic mice had a significantly greater insulin secretory response to both glucose and glucagon challenges (Fig. 2). Both the absolute and the percent increase in plasma insulin levels was greater in transgenic than wild-type mice.

We have previously reported a normal hypoglycemic response to subcutaneous insulin in transgenic mice. Using an identical protocol, we investigated the hypoglycemic effects of IGF-I and des (1-3) IGF-I in these mice. Fig. 3 depicts the hypoglycemic effects of IGF-I and des (1-3) IGF-I in transgenic and wild-type mice. Our previously published insulin tolerance tests data have been included for comparison (17). In wildtype mice IGF-I and des (1-3) IGF-I were approximately equi-

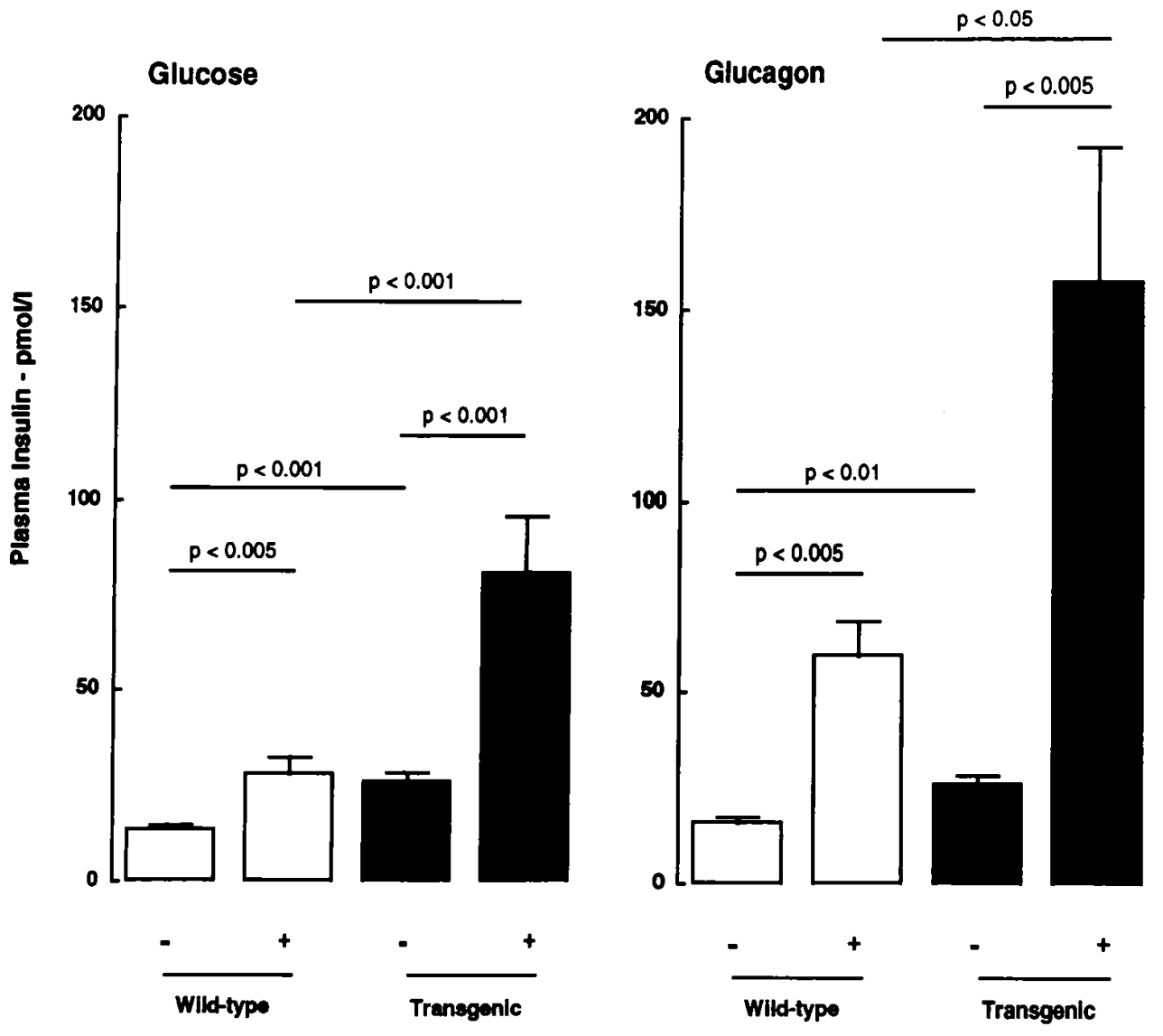

Figure 2. The effects of glucose and glucagon on insulin release in fasting 60-d-old, transgenic and wild-type mice. The data represent the mean \pm SEM for 8 mice per group. The significant differences between transgenic and wildtype mice groups are indicated. 


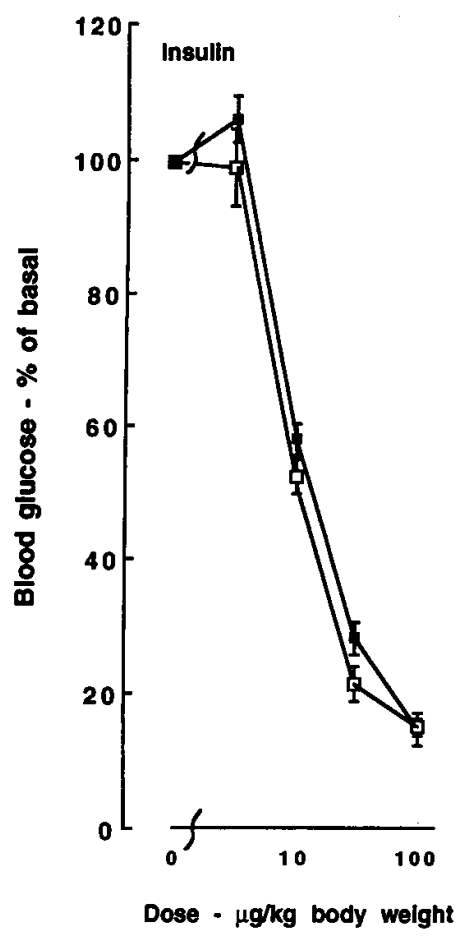

potent and only about $5-10 \%$ as potent as insulin in terms of lowering blood glucose. Transgenic and wild-type mice had identical hypoglycemic responses to insulin and des (1-3) IGF-I. The hypoglycemic effect of IGF-I was markedly attenuated in transgenic mice (Fig. 3). Indeed, at lower concentrations, IGF-I significantly increased blood glucose levels in transgenic mice. This hyperglycemic effect of IGF-I in transgenic mice is more apparent in Fig. 4 where the time course of action of IGF-I on blood glucose has been depicted. In saline-treated transgenic and wild-type mice there was a small decline in the blood glu-

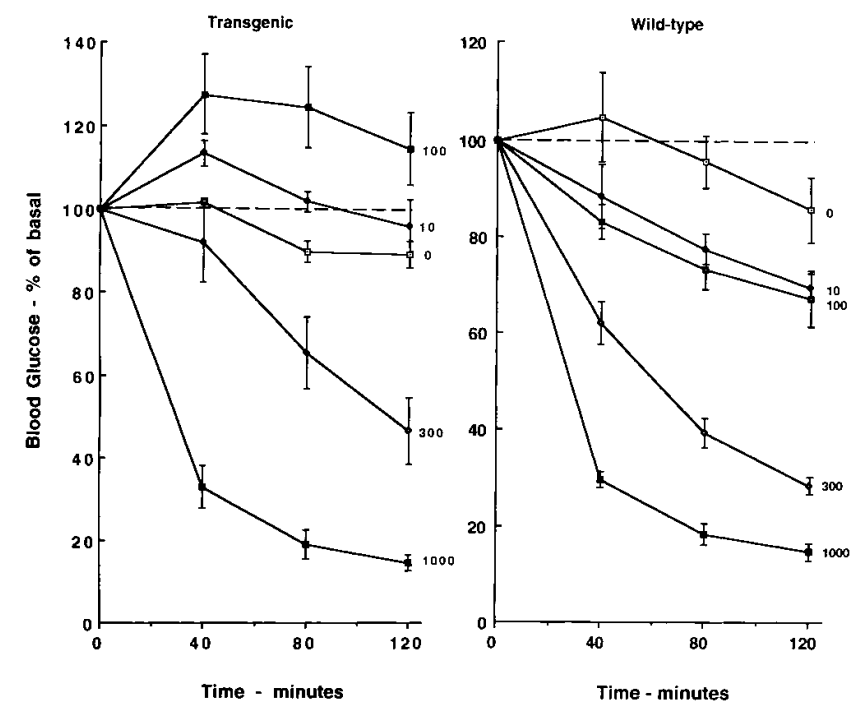

Figure 4. The time course of the blood glucose response to IGF-I in fasted male transgenic and wild-type mice. IGF-I was administered subcutaneously in various dose $0-1000 \mu \mathrm{g} / \mathrm{kg}$ body wt, in $100 \mu \mathrm{l}$ of saline. Blood glucose concentrations were expressed as a percentage of the basal values. The data represent the mean \pm SEM for 4-9 mice per point.

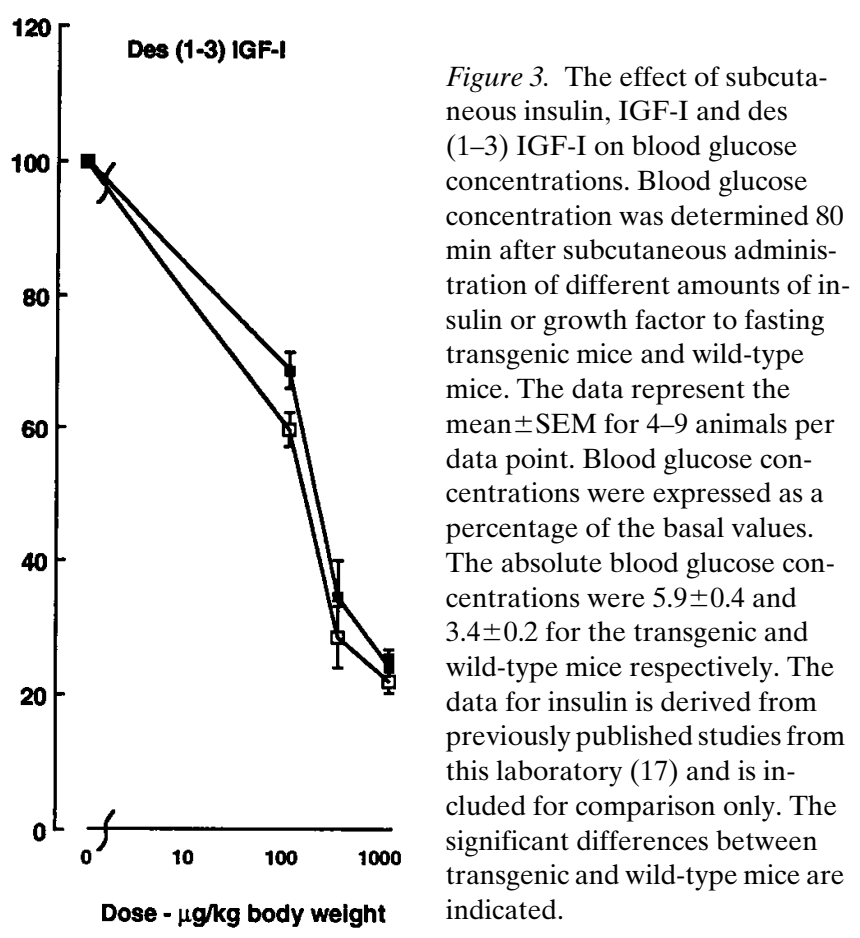

cose levels towards the end of the 120-min experiment. In contrast, there was a dose-dependent rise in blood glucose concentrations in transgenic mice that received the lower doses of IGF-I. This was not observed in wild-type mice. At 40 and 80 min postinjection of 10 and $100 \mu \mathrm{g} / \mathrm{kg}$ body wt of IGF-I, blood glucose levels were significantly higher than basal glucose levels, significantly higher than in wild-type mice which received the same doses of IGF-I, and significantly higher than transgenic mice which received only saline (Fig. 4). To determine whether the hyperglycemia induced by IGF-I administration to transgenic mice was due to a suppression of insulin secretion, insulin levels were measured in transgenic mice under basal fasting conditions and $40 \mathrm{~min}$ after administration of IGF-I, $100 \mu \mathrm{g} / \mathrm{kg}$ body weight. There was no significant change
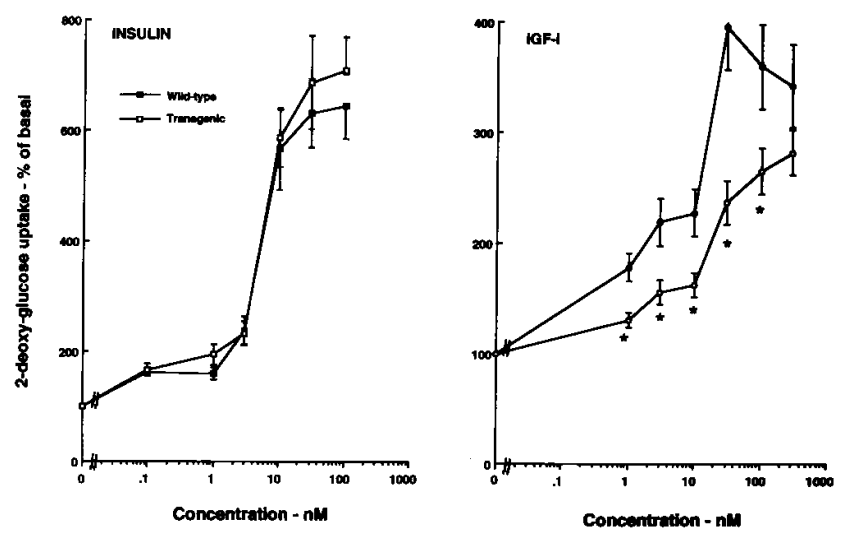

Figure 5. The effect of insulin and IGF-I on 2-deoxy- $\left[{ }^{3} \mathrm{H}\right]$-glucose uptake in isolated adipocytes from transgenic and wild-type mice. The data represents the mean \pm SEM for 7 to 10 separate pools of adipocytes where each pool was derived from 3 to 5 mice. Data have been expressed as a percentage of basal uptake which was not significantly different between transgenic and wild-type mice. * represents $P<$ 0.05 for the differences between the two groups of mice. 


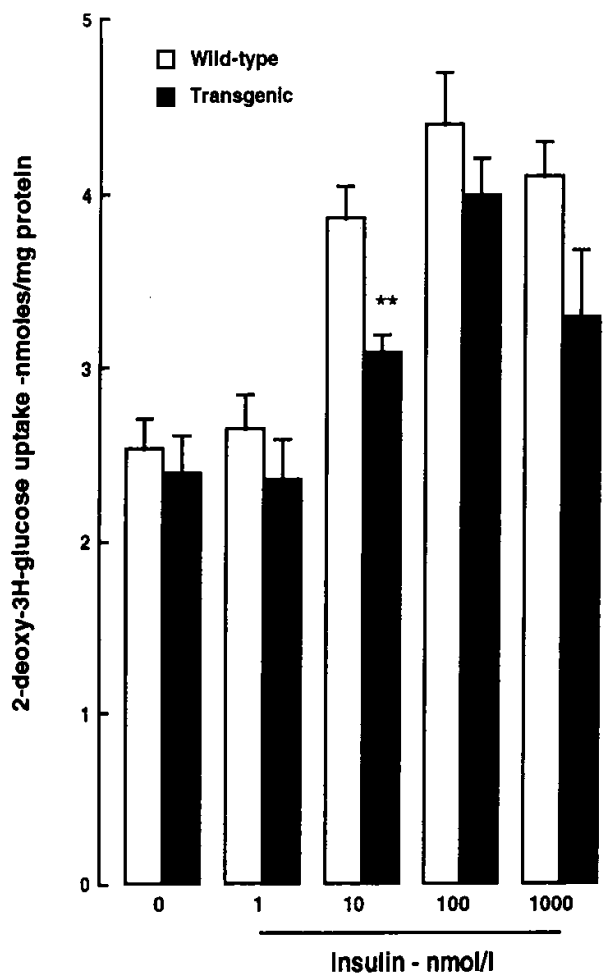

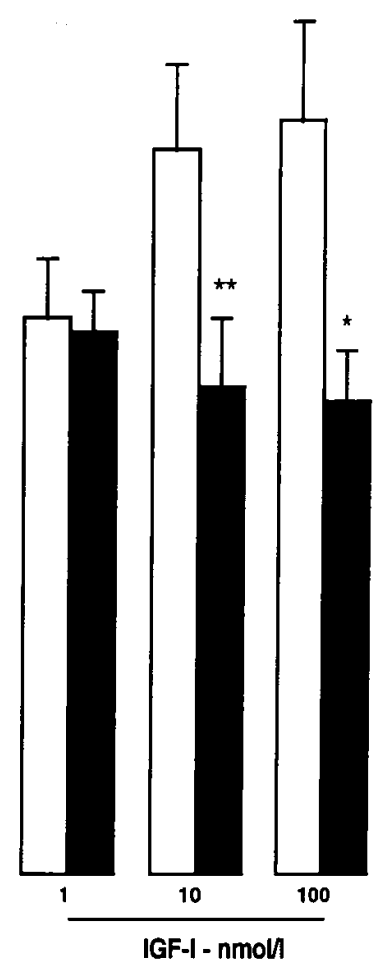

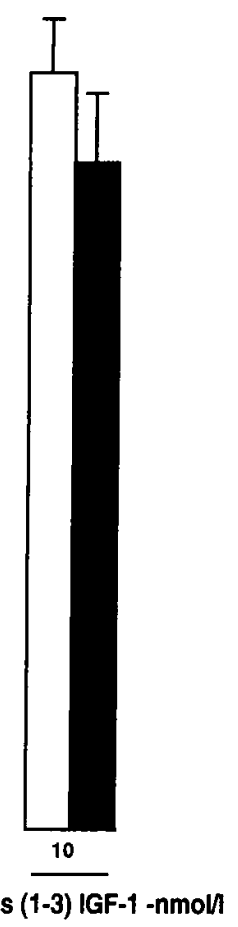

Figure 6. The effect of insulin, IGF-I and des (1-3) IGF-I on 2-deoxy- $\left[{ }^{3} \mathrm{H}\right]$-glucose uptake in isolated soleus muscle preparation from transgenic and wildtype mice. The data represents the mean \pm SEM for 5 to 15 separate muscles. * and ** represent $P<0.05$ and $P<0.005$ for the difference between the transgenic and wild-type mice. in plasma insulin levels; $23.5 \pm 0.8$ versus $25.1 \pm 1.6 \mathrm{pmol} / 1$ for basal and $40 \mathrm{~min}$ postinjection, respectively.

We next examined the effects of insulin and IGF-I on glucose transport in isolated adipocytes and soleus muscles from the transgenic and wild-type mice. As previously noted, IGF-I was markedly less potent than insulin in isolated adipocytes which are thought to be relatively deficient in IGF-I receptors. The half maximal effective IGF-I concentration was $\sim 20$ nmol/liter compared to $\sim 4 \mathrm{nmol} /$ liter for insulin. In addition the maximal IGF-I response was considerably less than the maximal response seen with insulin. Basal 2-deoxy-[$\left[{ }^{3} \mathrm{H}\right]$-glucose uptake was similar in adipocytes from transgenic and wild-type mice; $27 \pm 5$ vs. $33 \pm 5$ pmoles $/ 3 \mathrm{~min} / 100,000$ cells respectively. The insulin dose response in adipocytes from transgenic and wild-type mice were identical (Fig. 5). However, the IGF-I response was markedly attenuated in transgenic compared to wild-type mice.

In isolated soleus muscle, basal 2-deoxy-[ $\left.{ }^{3} \mathrm{H}\right]$-glucose uptake was similar in transgenic and wild-type mice; $2.52 \pm 0.18$ vs. $2.39 \pm 0.2 \mathrm{nmoles} / \mathrm{mg}$ of protein/15 min respectively. In soleus muscle from wild-type mice, Insulin, IGF-I, and des (1-3) IGF-I were equipotent in stimulating glucose transport (Fig. 6). In soleus muscle preparations from transgenic mice, there was a right shift of the insulin dose response curve compared to muscle from wild-type mice. The half-maximal insulin concentration for soleus muscle from transgenic mice was $11 \mathrm{nmol} / \mathrm{l}$ compared to $4 \mathrm{nmol} /$ liter for muscle from wild-type mice. In contrast to muscle from wild-type mice, IGF-I had no significant effect on 2-deoxy-[ $\left.{ }^{3} \mathrm{H}\right]$-glucose uptake in soleus muscle from transgenic mice. The effect of insulin and IGF-I on muscle glycogen synthesis was also measured in the soleus from transgenic and wild-type mice. In wild-type mice insulin, IGF-I and des (1-3) IGF-I were equipotent (Fig. 7). Both insulin and IGF-I, but not des (1-3) IGF-I were less potent in stimulating

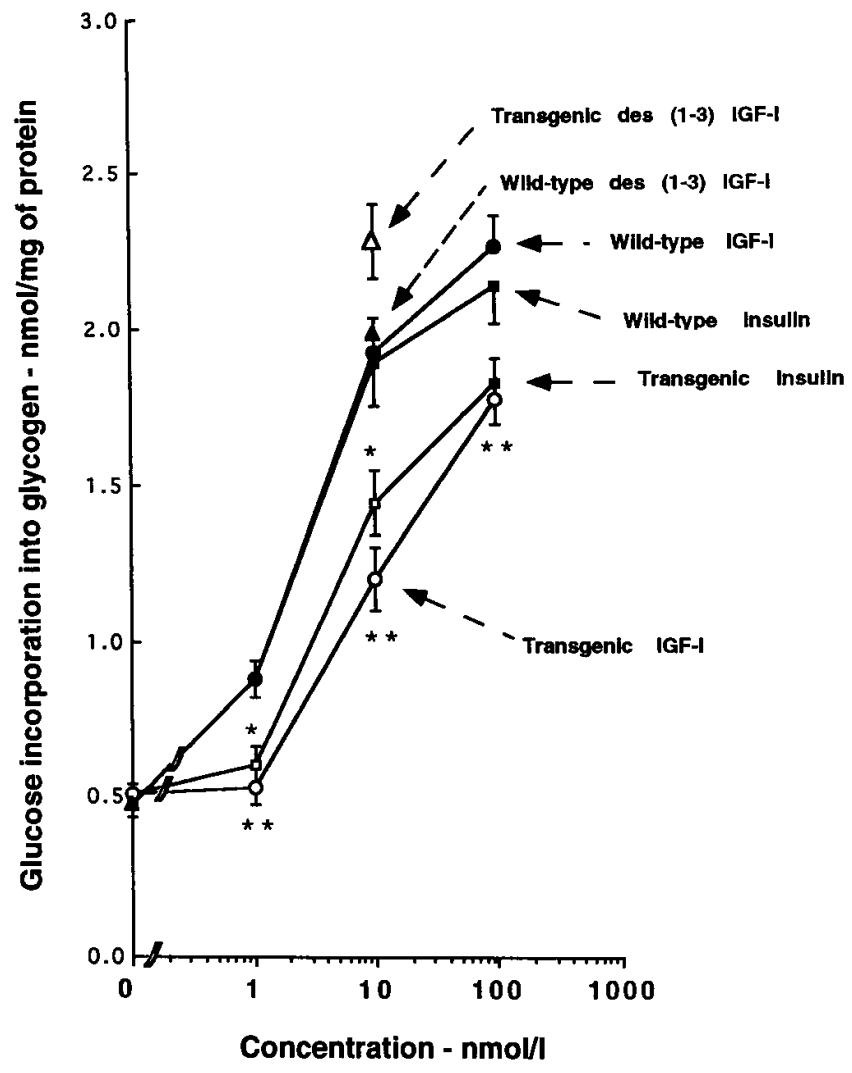

Figure 7. The effect of insulin, IGF-I and des (1-3) IGF-I on glycogen synthesis in isolated soleus muscle preparation from transgenic and wild-type mice. The data represents the mean \pm SEM for 5 to 10 separate muscles per group. * and ${ }^{* *}$ represent $P<0.05$ and $P<$ 0.005 for the difference between the transgenic and wild-type mice. 
Table II. Plasma Amino Acids in Fasting Wild-type and Transgenic Mice

\begin{tabular}{|c|c|c|c|}
\hline Amino acid & Wild-type mice & Transgenic mice & \\
\hline Taurine & $1312 \pm 82$ & $1404 \pm 123$ & \\
\hline Threonine & $206.0 \pm 9.5$ & $276.1 \pm 19.4$ & $P<0.007$ \\
\hline Asparagine & $60.0 \pm 2.9$ & $80.6 \pm 3.8$ & $P<0.005$ \\
\hline Glutamine & $77.6 \pm 8.4$ & $77.1 \pm 3.1$ & \\
\hline Glycine & $348.6 \pm 23.6$ & $334.0 \pm 18.9$ & \\
\hline Citrulline & $52.3 \pm 7.0$ & $65.4 \pm 7.8$ & \\
\hline Cystine & $4.6 \pm 0.7$ & $6.3 \pm 1.0$ & \\
\hline Isoleucine & $129.3 \pm 4.4$ & $144.0 \pm 7.2$ & \\
\hline Tyrosine & $71.3 \pm 2.3$ & $82.9 \pm 3.8$ & $P<0.023$ \\
\hline Ornithine & $52.9 \pm 4.5$ & $63.9 \pm 5.1$ & \\
\hline Histidine & $50.9 \pm 3.1$ & $55.9 \pm 3.7$ & \\
\hline Aspartic acid & $28.0 \pm 4.7$ & $25.6 \pm 2.0$ & \\
\hline Serine & $145.1 \pm 6.2$ & $186.3 \pm 12.5$ & $P<0.012$ \\
\hline Glutamic acid & $543.3 \pm 13.9$ & $618.0 \pm 43.1$ & \\
\hline Proline & $87.7 \pm 3.9$ & $117.6 \pm 6.5$ & $P<0.002$ \\
\hline Alanine & $464.9 \pm 48.8$ & $727.1 \pm 36.1$ & $P<0.001$ \\
\hline Valine & $298.1 \pm 19.9$ & $305.1 \pm 16.6$ & \\
\hline Methionine & $59.7 \pm 2.2$ & $88.0 \pm 3.72$ & $P<0.001$ \\
\hline Leucine & $210.3 \pm 13.7$ & $228.6 \pm 13.1$ & \\
\hline Phenylalanine & $83.3 \pm 4.0$ & $104.6 \pm 4.5$ & $P<0.004$ \\
\hline Lysine & $198.9 \pm 412.4$ & $314.9 \pm 18.1$ & $P<0.001$ \\
\hline Arginine & $93.0 \pm 7.1$ & $100.6 \pm 10.7$ & \\
\hline
\end{tabular}

Data represents the mean \pm SEM for seven mice per group.

glycogen synthesis in muscle from transgenic mice than wildtype mice. The half-maximal insulin concentrations for glucose incorporation into glycogen in soleus muscle from wild-type and transgenic mice was 2 and $10 \mathrm{nmol} /$ liter, respectively. Since IGF-I is a potent inhibitor of muscle protein catabolism, we measured plasma amino acids in fasting transgenic and wildtype mice (Table II). Of the 22 amino acids measured, 9 were significantly elevated in transgenic mice. Plasma concentrations of alanine, lysine, and methionine were the most markedly elevated.

The clearance and tissue uptake of 2-deoxy- $\left[{ }^{3} \mathrm{H}\right]$-glucose was determined in fasting mice. Because the blood glucose was significantly higher in transgenic than wild-type mice (5.64 \pm 0.62 vs. $3.10 \pm 0.21 \mathrm{mmol} /$ liter respectively, $P<0.002$ ) the amount of 2-deoxy- $\left[{ }^{3} \mathrm{H}\right]$-glucose administered was adjusted in a manner to ensure that the initial specific activity was not significantly different in the two groups of mice; $322.6 \pm 48.3$ vs. $318.2 \pm 42.3 \mathrm{cpm} / \mathrm{nmol}$ of glucose for wild-type and transgenic mice, respectively. The radioactivity in the circulation declined more rapidly in transgenic mice. After $40 \mathrm{~min}$ there was no significant difference in residual radioactivity in the blood between the transgenic and wild-type mice. Since $\sim 25 \%$ more 2-deoxy- $\left[{ }^{3} \mathrm{H}\right]$-glucose was administered to transgenic mice, these data indicated enhanced 2-deoxy-[$\left.{ }^{[} \mathrm{H}\right]$-glucose uptake from the circulation in transgenic mice. The decline in the specific activity of the circulating glucose pool in the two groups of mice is shown in Fig. 8. Since there is negligible efflux of 2-deoxy$\left[{ }^{3} \mathrm{H}\right]$-glucose from tissues and the radiolabeled is effectively not recycled over this time period, the decline in specific activity is a measure of dilution of the circulating 2-deoxy- $\left[{ }^{3} \mathrm{H}\right]$-glucose with glucose appearing in the circulation. The decline in

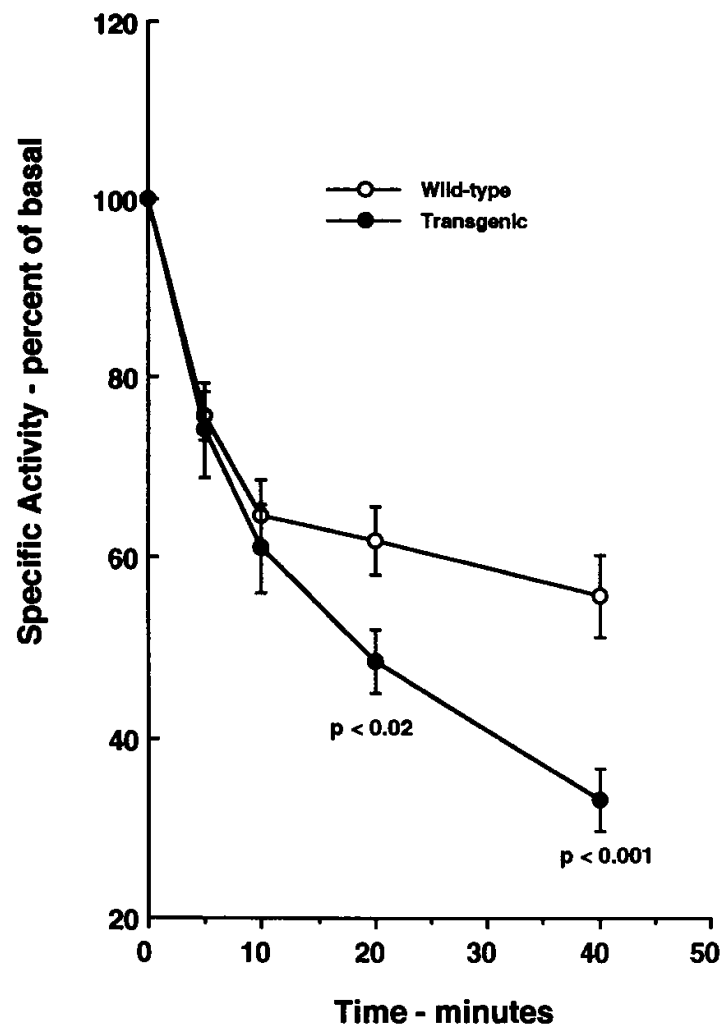

Figure 8 . The decline in specific activity of glucose in the circulation following administration of 2-deoxy- $\left[{ }^{3} \mathrm{H}\right]$-glucose to transgenic and wild-type mice. Blood was sampled at the indicated time points after administration of 2-deoxy- $\left[{ }^{3} \mathrm{H}\right]$-glucose via the tail vein. The specific activity of the blood glucose pool was expressed in terms of the basal specific activity at time zero. There was no significant difference in the basal specific activity between transgenic and wild-type mice. The significant differences between the two groups of mice are indicated. The data represent mean \pm SEM for 8 mice per group.

specific activity was significantly more marked in transgenic mice than wild-type mice.

The tissue accumulation of 2-deoxy- $\left[{ }^{3} \mathrm{H}\right]$-glucose was measured under basal fasting conditions. Significantly more glucose uptake was seen in the diaphragm, heart, liver, small intestine, rectus abdominus, soleus, and adipose tissue from transgenic mice (Table III).

\section{Discussion}

On a molar basis, the insulin-like growth factors are present in the circulation in a 100-fold excess compared to insulin. Although the IGFs have only about $5 \%$ of the insulin-like activity of insulin, they represent the vast majority of the insulin-like activity present in mammalian serum. Only a small percentage of the circulating IGF-I is unbound. However, the actual percentage of the total circulating IGF-I that is able to interact with the insulin receptor and exert the hypoglycemic effect is unclear. The data generated in this laboratory using a IGFBP-1 transgenic mouse model, together with previous reports of a hyperglycemic effect of human IGFBP-1 in rats (6) are consistent with the hypothesis that the IGFs do indeed have some role in glucose homeostasis. 
Table III. Tissue Glucose Utilization Index in Fasting Wildtype and Transgenic Mice

\begin{tabular}{lll}
\hline Tissue & \multicolumn{1}{c}{ Wild-type } & Transgenic \\
\hline Brain & $3.37 \pm 0.30$ & $3.28 \pm 0.07$ \\
Diaphragm & $1.02 \pm 0.163$ & $2.86 \pm 0.38^{\S}$ \\
Heart & $0.61 \pm 0.09$ & $1.63 \pm 0.23^{\S}$ \\
Liver & $1.35 \pm 0.18$ & $2.77 \pm 0.36^{\ddagger}$ \\
S. intestine & $2.63 \pm 0.32$ & $4.36 \pm 0.48^{\ddagger}$ \\
Kidney & $3.43 \pm 0.65$ & $4.90 \pm 1.07$ \\
Rectus abdominus & $1.57 \pm 0.21$ & $2.60 \pm 0.32^{*}$ \\
Adipose tissue & $0.35 \pm 0.03$ & $1.51 \pm 0.24^{\S}$ \\
Quadriceps & $0.82 \pm 0.17$ & $1.05 \pm 0.14$ \\
Soleus & $0.74 \pm 0.1$ & $1.95 \pm 0.61 *$
\end{tabular}

The GUI was derived from the tissue accumulation of 2-deoxy- $\left[{ }^{3} \mathrm{H}\right]$-glucose 6-phosphate divided by the integral of the specific activity over the 40 -min period. Data represent the mean \pm SEM for 8 to 10 mice per group and is expressed as nmol/100 mg of tissue. ${ }^{*} P<0.05$. ${ }^{\ddagger} P<0.01{ }^{\S} P<$ 0.005 for the differences between transgenic and wild-type mice.

In the present study, we demonstrated that fasting hyperglycemia develops gradually in the transgenic mice and is preceded by a period of normoglycemic hyperinsulinemia similar to that reported in animal models of type II diabetes and patients with this condition $(15,16)$. We have previously reported increased pancreatic islet size and number in transgenic mice compared to wild-type mice (17). Here we demonstrate that pancreatic insulin content is initially increased in transgenic mice but declines with age and is accompanied by the gradual onset of hyperglycemia. The phenomenon of pancreatic exhaustion is well described in type II diabetes and in that condition may represent an inherent pancreatic defect, glucose toxicity or a combination of both $(16,18)$.

Normoglycemia accompanied by hyperinsulinemia has been interpreted by some, to indicate the presence of insulin resistance (16). Although the insulin to glucose ratio was markedly elevated in transgenic pups, at 2 mo of age the insulin to glucose ratio was similar in the two groups of mice 4.62 vs. $4.13 \mathrm{pmol} / \mathrm{mol}$ for transgenic and wild-type mice, respectively. There was significant impairment of insulin-induced glucose uptake and glycogen synthesis in isolated soleus muscle. This may be explicable on the basis of glucose toxicity since impaired muscle glucose uptake and oxidation has been previously documented in hyperglycemic states (19). Alternatively, it may represent an intrinsic defect in insulin action resulting from inhibition of the IGF-I effect in muscle. Interestingly, the transgenic mice were equally responsive to insulin in terms of hypoglycemia. At any particular insulin dose, the same percentage decrease in blood glucose was observed in transgenic and wild-type mice. Since transgenic mice had higher fasting blood glucose levels the absolute decrease in blood glucose levels in response to a given dose of insulin was actually greater in transgenic than wild-type mice. Furthermore, no insulin resistance was demonstrable when insulininduced glucose uptake was quantified in isolated adipocytes. Thus, insulin resistance would not appear to be generalized to all tissues.

The enhanced 2-deoxy-[ $\left[{ }^{3} \mathrm{H}\right]$-glucose disappearance from the circulation and the increased uptake in a variety of tissues including skeletal muscle in the fasting transgenic mice sug- gests that the hyperglycemia more than compensates for any reduction in insulin-mediated glucose transport in muscle. Thus, unlike other animal models of type II diabetes mellitus where insulin resistance is easily demonstrated by an impaired hypoglycemic response to insulin, insulin resistance is not a generalized or prominent feature in IGFBP-1 transgenic mice. Thus, other mechanisms in addition to insulin resistance are likely to be responsible for the disturbed glucose homeostasis in IGFBP-1 transgenic mice. The hyperinsulinemia may represent a compensatory mechanism for the loss of other insulinlike activity in the serum, namely the IGFs. Although the majority of the IGF present in the circulation is bound to IGFBP-3, the concentration of this binding protein is very stable $(7,8)$. Thus, the turnover of IGF present in the ternary complex is relatively slow (7). In contrast to IGFBP-3, the levels of IGFBP-1 vary considerably throughout the day and are inversely regulated by insulin $(5,11,21,22)$. The unique pattern of regulation of IGFBP-1 expression suggests that this binding protein may have some role in modulating the free component of IGF-I and thus may be important in blood glucose control (5). Conditions characterized either by reduced insulin levels or reduced insulin action, for example insulin resistance induced by glucocorticoid excess, are associated with enhanced IGFBP-1 expression and elevated IGFBP-1 levels (9, 20, 23). Lewitt and Baxter have suggested that IGFBP-1 may have a role in counteracting the hypoglycemic effect of insulin (5). Our observations using the IGFBP-1 transgenic mouse model would support this hypothesis. This counter-regulator effect most likely is due to inhibition of the hypoglycemic effect of IGF-I. The serum levels of rat IGFBP-1 in these transgenic mice ranged as high as $79.8 \mathrm{ng} / \mathrm{ml}$ whereas IGFBP-1 levels are usually less than $1 \mathrm{ng} / \mathrm{ml}$ in rat (24) and are undetectable in wild-type mice using a rat IGFBP-1 assay (12). The elevated serum IGFBP-1 levels would be more than sufficient to effectively neutralize all the free IGF-I in the circulation of transgenic mice. Furthermore, since the transgene is widely expressed, tissue levels may exceed serum levels (12).

In contrast to the normal hypoglycemic effects of insulin in transgenic mice, the hypoglycemic effects of IGF-I were markedly attenuated. Indeed a hyperglycemic response was observed when small amounts of IGF-I were administered to transgenic mice. Interestingly, a similar modest hyperglycemic effect has been observed in rats and monkeys administered IGF-I as an IGF-I-IGFBP-3 complex and in rats given IGF-I complexed to IGF-I neutralizing monoclonal antibody $(25,26)$. The mechanism underlying this hyperglycemic response remains unclear. It does not appear to be due simply to suppression of endogenous insulin release since insulin levels were not decreased in transgenic mice at the time of the maximal rise in blood sugar level. Other workers have reported suppression of serum insulin levels in response to IGF-I infusion in man (27) and rats (28). This was not observed in the transgenic mice, possibly because the effects of IGF-I on the islets are blocked by local overexpression of IGFBP-1.

IGF-I has been shown to have a hypoaminoacidemic effect in both humans and rodents $(27,28)$. In normal rats, IGF-I selectively inhibits muscle protein breakdown (28), however, in diabetic rats IGF-I has little effect on muscle proteolysis and predominantly effects protein synthesis (29). In the latter setting insulin both stimulates protein synthesis and potently inhibits protein degradation (29). Indeed studies in diabetic rats have suggested a complex interactive effect of insulin and IGF-I 
on muscle protein metabolism (29). The elevated plasma amino acids concentrations demonstrated in the transgenic mice are likely to be a result of impaired action of IGF-I and/or insulin at the level of muscle.

While the transgenic mice demonstrated only modest fasting hyperglycemia, glycemic excursions after intraperitoneal glucose are markedly increased compared to wild-type mice (17). Glucose administration to fasting mice with the consequent insulin release would normally result in suppression of IGFBP-1 expression (10). It could be argued that the reduction in IGFBP-1levels after a glucose load in wild-type mice would enhance the hypoglycemic effect of IGF-I possibly by increasing the free unbound IGF-I concentration. In the transgenic mice where the expression of IGFBP-1 is constitutively upregulated, this compensatory mechanism would not occur.

Despite the decline in the insulin/glucose ratio and the agedependent reduction in pancreatic insulin content, 60-d-old transgenic mice still has the ability to respond when challenged with either glucose or glucagon. In response to these challenges the transgenic mice demonstrated more than adequate insulin secretory capacity. Thus the fasting hyperglycemia in these transgenic mice is not due to reduced insulin secretory capacity. However the marked decline in the insulin/glucose ratio with age suggests that there is some resetting of glucose mediated insulin secretory mechanism.

The data presented in this report provide clear evidence of disturbed glucose homeostasis in IGFBP-1 transgenic mice. Many of the characteristic features of type II diabetes mellitus are apparent in this animal model. These include, reduced birth weight $(12,30)$, a period of hyperinsulinemic normoglycemia preceding fasting hyperglycemia, (16) and a gradual decline in insulin secretion with age $(16,18)$. IGFBP-1 levels are elevated in diabetic patients, even those considered to have acceptable glycemic control as determined by hemoglobin A1c determinations (31). These elevated levels have been considered to be a consequence of insulin resistance. However, the data presented here suggest that elevated IGFBP-1 levels may themselves contribute to disturbed glucose homeostasis in diabetic patients. If this is the case, strategies to normalize IGFBP-1 levels or neutralize the effects of elevated IGFBP-1 levels may improve glycemic control in diabetes.

\section{Acknowledgments}

This research was supported by the Canadian Diabetes Association, the Medical Research Council of Canada and the H.E. Sellers Fund. L.J. Murphy is a recipient of an Medical Research Council of Canada Scientist award and an endowed Research Professorship in Metabolic diseases. S.T. Dhan is a recipient of a CDA postdoctoral fellowship.

\section{References}

1. Rechler, M.M. 1993.Insulin-like growth factor binding proteins. Vitam. Horm. 47:1-114.

2. Poggi, C., Y. Le Marchand-Brustel, J. Zapf, E.R. Froesch, and P. Freychet. 1979. Effects and binding of insulin-like growth factor I in the isolated soleus muscle of lean and obese mice: comparison with insulin. Endocrinology. 105:723-730

3. Zapf, J., C. Hauri, M. Waldvogel, and E.R. Froesch. 1986. Acute metabolic effects and half-lives of intravenously administered insulin-like growth factor I and II in normal and hypophysectomized rat. J. Clin. Invest. 77:1768-1775.

4. Meuli, C., J. Zapf, and E.R. Froesch. 1978. NSILA-carrier protein abolishes the action of nonsuppressible insulin-like activity (NSILA-S) on perfused rat heart. Diabetologia. 14:255-261.

5. Lewitt, M.S., and R.C. Baxter. 1991. Insulin-like growth factor binding pro- tein-1: a role in glucose counterregulation? Mol. Cell. Endocrinol. 79:C147-152.

6. Lewitt, M.S., G.S. Denyer, G.J. Cooney, and R.C. Baxter. 1991. Insulinlike growth factor binding protein-1 modulates blood glucose levels. Endocrinology. 129:2254-2256.

7. Baxter, R.C., and J.L. Martin. 1989. Structure of the Mr 140,000 growth hormone-dependent insulin-like growth factor binding protein complex: determination by reconstitution and affinity labeling. Proc. Natl. Acad. Sci. USA. 86: 6898-6902.

8. Guler, H.-P., J. Zapf, C. Schmid, and E.R. Froesch. 1989. Insulin-like growth factors I and II in healthy man. Estimations of half-lives and production rates. Acta Endocrinol. 121:753-758.

9. Murphy, L.J., J. Luo, and C. Seneviratne. 1991. Hormonal regulation of insulin-like growth factor binding protein-1 expression in the rat. $A d v$. Exp. Med. Biol. 293:149-161.

10. Murphy, L.J., C. Seneviratne, P. Moreira, and R. Reid. 1991. Enhanced expression of insulin-like growth factor binding protein-I in the fasted rat: the effects of insulin and growth hormone administration. Endocrinology. 128:689-696.

11. Baxter, R.C., and C.T. Cowell. 1987. Diurnal rhythm of growth hormone-independent binding protein for insulin-like growth factors in human plasma. J. Clin. Endocrinol. Metab. 65:432-440.

12. Rajkumar, K., D. Barron, M.S. Lewitt, and L.J. Murphy. 1995. Growth retardation and hyperglycemia in insulin-like growth factor binding protein-1 transgenic mice. Endocrinology. 136:4029-4034.

13. Pipeleers, D.G., P.A. InT'Veld, M. Van de Winkel, E. Maes, F.C. Schuit, and W. Gepts. 1985. A new in vitro model for the study of pancreatic A and B cells. Endocrinology. 117:806-816.

14. Ramos, P., and E. Herrera. 1995. Reversion of insulin resistance in the rat during late pregnancy by 72-h glucose infusion. Am. J. Physiol. 269:E858-863.

15. Tokuyama, Y., J. Sturis, A.M. DePaoli, J. Takeda, M. Stoffel, J. Tang, X. Sun, K.S. Polonsky, and G.I. Bell. 1995. Evolution of b-cell dysfunction in the male zucker diabetic fatty rat. Diabetes. 44:1447-1457.

16. DeFronzo, R.A., R.C. Bonadonna, E. Ferrannini. 1992. Pathogenesis of NIDDM: a balanced overview. Diabetes Care. 15:318-368.

17. Rajkumar, K., S.T. Dheen, and L.J. Murphy. 1996. Hyperglycemia and impaired glucose tolerance in insulin-like growth factor binding protein-1 transgenic mice. Am. J. Physiol. 270:E565-571.

18. Porte, D., Jr. 1991. Banting lecture 1990: $\beta$-cells in type II diabetes mellitus. Diabetes. 40:166-180.

19. Davidson, M.B., C. Bouch, N. Venkatesan, and R.G. Karjala. 1994. Impaired glucose transport in skeletal muscle but normal GLUT-4 tissue distribution in glucose-infused rats. Am. J. Physiol. 267:E808-813.

20. Lee, P.D.K., C.A. Conover, and D.R. Powell. 1993. Regulation and function of insulin-like growth factor-binding protein-1. Proc. Soc. Exptl. Biol. Med. 204:4-29.

21. Suikkari, A.-M., V.A. Koivisto, R. Koistinen, M. Seppala, and H. YkiJarvivnen. 1989. Dose-response characteristics for suppression of low molecular weight plasma insulin-like growth factor-binding protein by insulin. J. Clin. Endocrinol. Metab. 68:135-140.

22. Suikkari, A.-M., V.A. Koivisto, E.-M. Rutanen, H. Yki-Jarvinen, S.-L. Karonen, and M. Seppala. 1988. Insulin regulates the serum levels of low molecular weight insulin-like growth factor-binding protein. J. Clin. Endocrinol. Metab. 66:266-272.

23. Luo, J., R. Reid, and L.J. Murphy. 1990. Dexamethazone increases hepatic insulin-like growth factor-1 (IGFBP-1) expression and serum IGFBP-1 concentration in the rat. Endocrinology. 127:1456-1462.

24. Lewitt, M.S., H. Saunders, and R.C. Baxter. 1992. Regulation of rat insulin-like growth factor-binding protein-1: the effect of insulin-induced hypoglycemia. Endocrinology. 131:2357-2364.

25. Sommers, A., J.A. Moore, C.M. Bagi, D.K. Schmidt, S.S. Chu, C. Liu, E.R. CeLeon, and S.W. Adams. 1995. Pharmacokinetics and bioavailability of rhIGF-I/IGFBP-3 in the rat and monkey. Proc. 3rd International Symposium on Insulin-like Growth Factor Binding Proteins. p37 (Abstr.)

26. Pell, J.M., H.C. Flick-Smith, S. Dye, and R.A. Hill. 1995. Further characterization of an IGF-I enhancing antibody: actions on IGF-I-induced hypoglycemia and interaction with the analogue LR ${ }^{3}$ IGF-I. Proc. 3rd International Symposium on Insulin-like Growth Factor Binding Proteins. p38 (Abstr.)

27. Boulware, S.D., W.V. Tamborlane, L.S. Matthews, and R.S. Sherwin. 1992.Diverse effects of insulin-like growth factor I on glucose, lipid, and amino acid metabolism. Am. J. Physiol. E130-E133.

28. Jacob, R., E. Barrett, G. Plewe, K.D. Fagin, and R.S. Sherwin. 1989. Acute effects of insulin-like growth factor I on glucose and amino acid metabolism in the awake fasted rat. J. Clin. Invest. 83:1717-1723.

29. Thomas, F.M., S.E. Knowles, P.C. Owens, J.L. Burgoyne, C.S. Chandler, and F.J. Ballard. 1996. Conjoint IGF-I and insulin infusion shows diverse interactive effects in diabetic rats. Diabetes. 45:170-177.

30. Phipps, K., D.J.P. Barker, C.N. Hales, C.H.D. Fall, C. Osmond, and P.M.S. Clark. 1993. Fetal growth and impaired glucose tolerance in men and women. Diabetologia. 36:225-228.

31. Brismar, K., E. Fernqvist-Forbes, J. Wahren, and K. Hall. 1994. Effect of insulin on the hepatic production of insulin-like growth factor-binding protein-1 (IGFBP-1), IGFBP-3 and IGF-I in insulin dependent diabetes. J. Clin. Endocrinol. Metab. 79:872-878. 